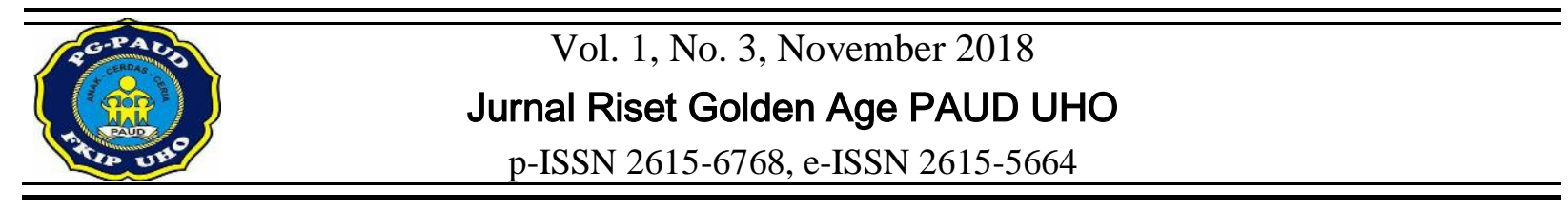

\title{
MENINGKATKAN KEMAMPUAN INTERPERSONAL MELALUI METODE BERMAIN
} PERAN

\author{
Yeni Febrianti Asril ${ }^{1)}$, Husein Ibrahim ${ }^{1)}$ \\ ${ }^{1}$ Jurusan PG-PAUD, Universitas Halu Oleo. Jln. H.E.A Mokodompit, Kendari 93232, Indonesia.
}

\begin{abstract}
Abstrak
Penelitian ini bertujuan untuk meningkatkan kemampuan interpersonal melalui metode bermain peran di kelompok B TK Yaa Bunayya Hidayatullah Kendari. Jenis penelitian ini adalah penelitian tindakan kelas (PTK).Penelitian ini dilaksanakan selama dua siklus dimana setiap siklus terdiri dari tiga kali pertemuan. Tahap-tahap dalam penelitian ini mengikuti prosedur penelitian tindakan kelas, yaitu: (1) perencanaan, (2) pelaksanaan, (3) observasi atau pengamatan, dan (4) refleksi. Subjek dalam penelitian ini adalah guru dan anak didik di Kelompok B TK Yaa Bunayya Hidayatullah Kendari yang berjumlah 15 anak didik 9 laki-laki 6 perempuan. Berdasarkan analisis data diperolah hasil evaluasi kemampuan interpersonal metode bermain peran sebesar $60 \%$. Sedangka pada siklus II, persentase aktivitas mengajar guru meningkat menjadi 92,31\%, sedangkan persentase kegiatan belajar anak meningkat menjadi $92,31 \%$. Hasil evaluasi kemampuan interpersonal melalui metode bermain peran sebesar $80 \%$ Dengan demikian dapat disimpulkan bahwa kemampuan interpersonaldi Kelompok B TK Yaa Bunayya Hidayatullah Kendari dapat ditingkatkan melalui metode bermain peran.
\end{abstract}

Kata Kunci: Kemampuan Interpersonal, Metode Bermain Peran, Anak.

\section{THE IMPROVING OF CHILDREN INTERPERSONAL ABILITY LANGUAGE THROUGH ROLE PLAYING METHODS}

\begin{abstract}
This research aimed to improve of Children Interpersonal Ability Through Role playing methods at group B TK Ya Bunayya Hidayatullah Kendari. This research was the classroom action research. That conducted in two cycles by follows of the classroom action research procedure, that's: (a) planning, (b) action, (c) observation and evalution, and (d) reflection. The subjects in this study were teachers and students in group B TK Ya Bunayya Hidayatullah Kendari which 15 people consist of 9 boys and 6 girls. Based on data analysis that the evaluation of children interpersonal through the method of playing a role of $60 \%$. While in cycle II, the percentage of teacher teaching activity increased to $92,31 \%$, while the percentage of children's learning activities increased to $92,31 \%$.the result of ovaluvation of interpersonal ability through role playing method equal to $80 \%$. Thus it can be concluded that interpersonal ability in group B TK Ya Bunayya Hidayatullah Kendari can be improved through role playing methods.
\end{abstract}

Keywords: Interpersonal Ability, Role Playing Methods, Child

\section{PENDAHULUAN}

Dalam Undang-Undang No. 20 tahun 2003 tentang Sistem Pendidikan Nasional, disebutkan bahwa pendidikan adalah usaha sadar dan terencana untuk mewujudkan suasana belajar dan proses pembelajaran agar peserta didik secara aktif mengembangkan potensi dirinya untuk memiliki kekuatan spiritual keagamaan, pengendalian diri, kepribadian, kecerdasan, akhlak mulia, serta keterampilan yang diperlukan dirinya, masyarakat, bangsa, dan negara (Fadlillah, 2012: 65).

Para pakar pendidikan dalam Fadlillah, (2012: 65), pendidikan anak usia dini ialah suatu proses pembinaan tumbuh kembang anak usia lahir hingga enam tahun secara menyeluruh, yang mencakup aspek fisik dan non fisik, dengan memberikan rangsangan bagi perkembangan jasmani, rohani (moral dan spiritual), motorik, akal pikir, emosional, dan sosial yang tepat agar anak dapat tumbuh dan berkembang secara optimal. 
Setiap potensi kemampuan yang ada pada anak, sebaiknya bukan saja dibiarkan menjadi potensi semata, namun harus dibina pertumbuhannya melalui orang dewasa yang ada disekitar kehidupan anak sehingga dapat menjadi sikap dan perilaku nyata sehari-hari bagi anak tersebut (Gardner, 2009:7).

Kemampuan emosional yang dapat melahirkan kemampuan interpersonal melalui rangsangan-rangsangan orang-orang yang ada disekitarnya.Dengan Kemampuan interpersonal yang tinggi, maka komunikasi antar pribadi akan terjalin dengan baik sehingga nanti akan memberikan pengaruh positif pada aspek perkembangan pada diri anak tersebut juga pada anak lainnya.

Kecerdasan interpersonal merupakan salah satu bentuk kecerdasan yang memiliki peran penting dalam kehidupan manusia, karena manusia tidak bisa menyendiri, banyak kegiatan dalam hidup manusia yang terkait dengan orang lain. Anak-anak yang gagal dalam mengembangkan kecerdasan interpersonal akan mengalami banyak hambatan dalam dunia sosialnya, akibatnya mereka mudah tersisihkan secara sosial, seringkali konflik interpersonal juga menghambat anak untuk mengembangkan dunia sosialnya secara matang.

May Lwin, ciri-ciri anak yang memiliki kecerdasan interpersonal yang tinggi yaitu berteman dan berkenalan dengan mudah, suka berada di sekitar orang lain, ingin tahu mengenai orang lain dan ramah terhadap orang asing, menggunakan bersama mainanya dan berbagi makanan dengan teman-temannya, mengalah kepada anak-anak lain, mengetahui bagaimana menuggu gilirannya selama bermain, mau memuji teman/orang lain, mengajak teman untuk bermain/belajar (May, 2008: 205). tersebut.

Tupper, individu yang tingggi kecerdasan interpersonalnya akan mampu menjalin komunikasi yang efektif dengan orang lain, berempati secara baik, mengembangkan hubungan yang harmonis dengan orang lain, dapat dengan cepat memahami temperamen, sifat, suasana hati, motif orang lain (Safaria, . 23).

Berdasarkan pengertian yang telah dipaparkan di atas dapat ditegaskan bahwa kecerdasan interpersonal merupakan kemampuan yang sangat penting bagi manusia. Kecerdasan interpersonal adalah kemampuan seseorang untuk memahami perasaan orang lain,suasana hati, sifat, empati , memecahkan masalah bersama,memahami maksud dan keinginan orang lain dan berkomunikasi secara efektif sehingga terjalin bekerjasama dalam kelompok.

Berdasarkan observasi awal di TK Yaa Bunayya Hidayatullah Kendari kegiatan pembelajaran sehari-hari dilaksanakan dengan posisi duduk anak yang konvensional dimana anak duduk menghadap papan tulis dan mendengarkan penjelasan guru layaknya kegiatan pembelajaran di jenjang pendidikan yang lebih tinggi. Kegiatan pembelajaran yang seperti tidak dapat mengembangkan kecerdasan interpersonal anak karena tidak ada kesempatan kepada masing-masing anak untuk menjalin interaksi dengan teman sebayanya. Hal ini tampak pada keadaan di kelas B dimana anak masih memiliki sifat egois yang tinggi, mau menang sendiri, pendiam, anak tidak mau bermain dengan teman yang lain yang bukan teman dekatnya, tidak mau bekerja sama dengan teman, kurang percaya diri dan bahkan ada anak yang bermain sendiri tanpa mempedulikan teman yang ada disekitarnya.

Sujiono dan sujiono menguraikan bahwa cara mengembangkan kecerdasan interpersonal pada anak , yakni (1) mengembangkan dukungan kelompok, (2) menetapkan aturan tingkah laku (3) member tanggung jawab di rumah, (4) bersama sama menyelesaikan konflik ,(5) melakukan kegiatan social di lingkungan ,6) menghargai perbedaan pendapat antara anak dan teman sebaya, (7) menumbuhkan sikap ramah dan memahami keragaman budaya lingkungan social ,dan (8) melatih kesabaran menunggu giliran, (9) berbicara serta mendengarkan pembicaraan orang lain terlebih dahulu (Nurani \& sujiono, 2010: 61).

Masitoh dkk mengemukakan bahwa metode bermain peran adalah suatu cara memainkan peran dalam suatu ceita tertentu yang menuntut kerjasama secara utuh diantara para pemainnya. Sedangkan Moeslichatoen mengatakan bahwa bermain peran adalah bermain yang menggunakan daya khayal yaitu dengan memakai bahasa atau berpura-pura bertingkah laku seperti benda tertentu, situasi tertentu, atau orang tertentu, dan binatang tertentu yang dalam dunia nyata tidak dilakukan (Aunurrahman, 2009: 34).

Bermain peran dapat meningkatkan pembendaharaan kosa kata, spontanitas dan kelancaran anak berbicara dan keterampilan anak berkomunikasi. 
Sanjaya mengemukakan bahwa bermain peran merupakan salah satu aktivitas yang penting bagi pertumbuhan anak karena dapat mengembangkan beragam potensi seperti spiritual, emosional, intelektual, sosial dan juga fisiknya (Sanjaya, 2009: 25).

Bermain peran dapat menjadi ajang belajar bagi anak, baik belajar membaca, berhitung, mempelajari proses atau alur dalam rangka mengerjakan sesuatu, mengenal tata tertib dan tata cara di suatu tempat, yang semua ada dalam kehidupan (Dimyati, 2006, p. 39). Menurut Miller dramatic play atau bermain peran adalah permainan yang di perankan anak anak menyerupai kehidupan sehari hari dalam keluarga maupun masyarakat (Miller, 2002: 81).

Metode bermain peran menurut Dimiati Mujiono adalah salah satu bentuk permainan pendidikan yang digunakan untuk menjelaskan perasaan, sikap, tingkah laku dan nilai, dengan tujuan untuk menghayati perasaan, sudut pandang dan cara berfikir orang lain. Melalui metode bermain peran anak diajak untuk belajar memecahkan metode pribadi, denganbantuan kelompok sosial yang anggotanya temantemannya sendiri. Dengan kata lain metode ini berupaya membantu individu melalui proses kelompok sosial (Hilda, 2012: 36). Yuliani nurani sujiono mengungkapkan bermain peran adalah kegiatan yang berfokus pada kegiatan dramatisasi,tempat untuk anak bermain memerankan tugas tugas anggota keluarga, tatacara dan kebiasaan dalam keluarga dengan berbagai perlengkapan rumah tangga serta kegiatan dilingkungan sekitarnya (Nurani \& sujiono, 2010: 81).

Hasan menyatakan proses belajar menggunakan metode bermain peran diharapkan anak mampu menghayati tokoh yang dikehendaki, keberhasilan anak dalan menghayati peran itu akan menentukan apakah proses pemahaman, penghargaan dan identifikasi diri terhadap nilai berkembang (Abdulah, 1996: 266).

Mulyasa terdapat empat asumsi yang mendasari pembelajaran bermain peran. Pertama, peserta didik dimungkinkan untuk menciptakan analogi mengenai situasi kehidupan nyata. Kedua, bermain peran memungkin para peserta didik untuk mengungkapkan perasaannya yang tidak dapat dikenal tanpa bercermin pada orang lain. Ketiga, berasumsi bahwa emosi dan ide-ide dapat diangkat ketaraf sadar untuk kemudian diangkat melalui proses kelompok. Keempat, berasumsi bahwa proses psikologis yang tersembunyi, berupa sikap, nilai, perasaan dan sistem keyakinan, dapat diangkat ke taraf sadar melalui kombinasi pemeranan secara spontan (Mulyasa, 2004: 141).

\section{METODE}

Jenis yang akan digunakan dalam penelitian ini adalah Penelitian Tindakan Kelas (PTK). Menurut Hopkins dalam Rochiati (2009: 11) penelitian tindakan kelas adalah penelitian yang mengkombinasikan prosedur penelitian dengan tindakan substantif, suatu tindakan yang dilakukan dalam disiplin inkuiri, atau suatu usaha seseorang untuk memahami apa yang sedang terjadi, sambil terlibat dalam sebuah proses perbaikan dan perubahan.

Tempat penelitian ini dilakukan di Kelompok B TK Yaa Bunayya Hidayatullah Kendari. Waktu pelaksanaan penelitian ini dilakukan terhitung mulai pada bulan Februari sampai Maret 2016 semester genap tahun ajaran $2015 / 2016$. Subyek penelitian tindakan kelas ini adalah guru dan 15 anak dengan 6 anak perempuan dan 9 anak laki-laki kelompok B TK Yaa Bunayya Hidayatullah Kendari.

Faktor yang diteliti dan diamati dalam penelitian tindakan kelas ini adalah sebagai berikut: 1) Faktor anak didik, mengamati aktivitas anak dalam mengikuti proses pembelajaran tentang peningkatan kemampuan visual spasial melalui kegiatan bermain bongkar pasang puzzle logika di Kelompok B TK Yaa Bunayya Hidayatullah Kendari, 2) Faktor guru, mengamati aktivitas guru dalam melakukan kegiatan, 3) Hasil belajar anak.

Penelitian ini direncanakan dua siklus dan masing-masing siklus terdiri atas empat kali pertemuan. Secara umum, terdapat empat langkah dalam melakukan PTK, yaitu (1) perencanaan; (2) pelaksanaan; (3) pengamatan; (4) refleksi (Arikunto, 2006 dalam Suyadi, 2010: 49).

Teknik pengumpulan data yang dilakukan pada penelitian ini dengan menggunakan cara pengamatan/observasi, wawancara, dan dokumentasi. 1) Pengamatan/observasi adalah suatu teknik yang dapat dilakukan guru untuk mendapatkan berbagai informasi atau data tentang perkembangan dan permasalahan anak, 2). Wawancara dilakukan dengan berkomunikasi kepada guru dan kepala sekolah. 3) Dokumentasi yang digunakan dalam penelitian ini adalah mengambil data anak berupa hasil karya anak pada saat melakukan proses 
pembelajaran di sekolah dan foto-foto dalam proses pembelajaran berlangsung sebagai data yang mendukung untuk dianalisis.

Teknik analisis data yang digunakan dalam penelitian ini disesuaikan dengan teknik penilaian di Taman Kanak-kanak yaitu dengan menggunakan tanda sebagai berikut: * = Belum Berkembang $(\mathrm{BB}), * *=$ Mulai Berkembang $(\mathrm{MB}), * * *=$ Berkembang Sesuai Harapan $(\mathrm{BSH}), * * * *=$ Berkembang Sangat Baik (BSB) (Depdiknas, 2004: 26).

Penelitian tindakan kelas ini dikatakan berhasil apabila anak secara perorangan dan klasikal melaksanakan rencana kegiatan pembelajaran dengan jumlah ketuntasan belajar sudah mencapai nilai $75 \%$ dari jumlah anak Kelompok B TK Yaa Bunayya Hidayatullah Kendari mencapai nilai Berkembang Sesuai Harapan (BSH) dan Berkembang Sangat Baik (BSB) sehingga dikatakan pelaksanaan pembelajaran berhasil.

\section{HASIL DAN PEMBAHASAN}

Kondisi Kemampuan awal anak dalam proses pembelajaran berbahasa belum berkembang dengan baik dengan hasil persentase anak yang memperoleh bintang $(* * * *)$ dan bintang $(* * *)$ atau Berkembang Sesuai Harapan (BSH) dan Berkembang Sangat Baik (BSB) hanya mencapai $40 \%$ atau 6 orang anak. Hasil dari observasi awal apabila dibandingkan dengan pelaksanaan siklus I terlihat adanya peningkatan sebesar $20 \%$ sehingga hasil yang diperoleh menjadi $60 \%$, namun belum mencapai indikator kinerja yang ditetapkan yaitu $\geq 75 \%$, sehingga perlu dilaksanakan siklus II. Hal ini disebabkan kerena pada pelaksanaan siklus I terdapat beberapa kelemahan guru dalam proses pembelajaran dengan menggunakan metode bermain peran, sehingga perlu dilakukan suatu perbaikan pada siklus II agar indikator kinerja yang diharapkan dapat tercapai.

Hasil yang diperoleh dalam pelaksanaan siklus II ternyata mengalami peningkatan $20 \%$, sehingga hasil yang diperoleh menjadi $80 \%$ dengan rincian 12 anak yang memperoleh bintang $(* * * *)$ atau berkembang sangat baik (BSB) dan bintang (***) atau Berkembang Sesuai Harapan (BSH), maka dapat dilakukan analisis keberhasilan tindakan secara klasikal dan diperoleh hasil seperti tampak pada histogram berikut ini:

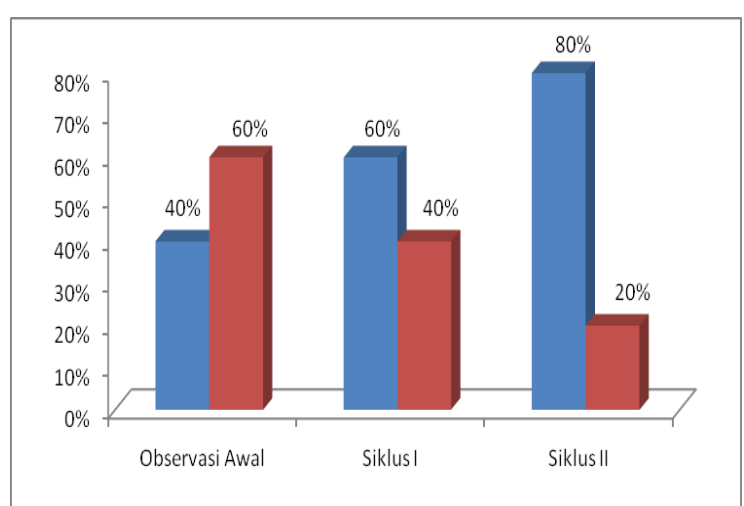

Gambar 1. Grafik Data Peningkatan Kemampuan Pengenalan Kosakata Bahasa Inggris Anak melalui Pengimplementasian Metode Total Physical Response

Selama kegiatan penelitian berlangsung, dari data hasil yang diperoleh sebagaimana dideskripsikan pada halaman sebelumnya, dapat dikatakan bahwa kegiatan pembelajaran dalam meningkatkan kemampuan interpersonal anak yang dirancang dan dilaksanakan oleh peneliti yang bekerjasama dengan guru Kelompok BTK Ya Bunayya Hidayatullah Kendari selaku observer pada setiap pelaksanaanpembelajaran siklus I dan siklus II, sangat memberikan manfaat pada anak dan peneliti melalui pengalaman langsung, serta Kemampuan interpersonal dalam berbahasa anak yang mengalami peningkatan. Jika dilihat dari tahapan observasi awal penelitian yang hanya mencapai 40\%,mengalami peningkatan pada siklus I sebesar $60 \%$ dan pada siklus II pada tindakan siklus II mencapai persentase sebesar $80 \%$, menunjukkan hasil yang lebih baik dari sebelumnya, karena indikator kinerja yang ditetapkan telah tercapai yaitu minimal $75 \%$ maka penelitian ini dapat dihentikan.

\section{KESIMPULAN DAN SARAN}

\section{Kesimpulan}

Berdasarkan hasil observasi guru pada pelaksanaan siklus I, memperoleh persentase sebesar $69,23 \%$ dan pada siklus II meningkat menjadi $92,31 \%$. Sedangkan hasil observasi aktivitas anak pada pelaksanaan siklus I, memperoleh persentase sebesar $53,85 \%$ dan pada siklus II meningkat menjadi $92,31 \%$, nilai tersebut telah memenuhi standar ketuntasan dari segi proses yaitu sebesar $\geq 85 \%$.

Berdasarkan hasil belajar Kemampuaninterpersonal melalui metode bermain peran pada saat hasil observasi awal 
sebelum tindakan sebesar $40 \%$, pada siklus I meningkat menjadi $60 \%$ dan pada siklus II lebih meningkat lagi menjadi $80 \%$, nilai tersebut telah memenuhi standar ketuntasan hasil belajar yang telah ditentukan dari TK yaitu sebesar $\geq 75 \%$. Dengan demikian dapat disimpulkan bahwa Kemampuan interpersonal dapat ditingkatkan melalui metode bermain peran di Kelompok B TK Ya Bunayya Hidayatullah Kendari selama dua siklus,.

\section{Saran}

Berdasarkan kesimpulan hasil penelitian, maka peneliti memberikan beberapa saran sebagai berikut: 1) Bagi guru, agar pembelajaran lebih menarik perhatian anak, hendaknya guru lebih kreatif dalam menciptakan suasana pembelajaran yang menyenangkan bagi anak., 2) Bagi sekolah, hendaknya mampu menyediakan media atau alat peraga lain yang mampu meningkatkan kemampuan visual spasial, 3) Bagi peneliti, diharapkan dapat meningkatkan kemampuan interpersonal anak dengan menggunakan media atau alat peraga yang lain.

\section{DAFTAR PUSTAKA}

Abdulah, H. 1996. Psikologi Perkembangan Anak. Jakarta: Nextendo.

Aunurrahman. 2009. Belajar dan Pembelajaran. Bandung: Alfabeta. Depdiknas. 2004. Pedoman Penilaian di Taman KanakKanak. Jakarta: Depdiknas.

Dimyati, M. 2006. Belajar dan Pembelajaran. Jakarta: Rineka Cipta.

Fadlillah, Muhammad. 2012. Desain Pembelajaran PAUD: Panduan untuk Pendidik, Mahasiswa, \& Pengelola Pendidikan Anak Usia Dini. Tinjauan Teoretik \& Praktik. Jogjakarta: Ar-Ruzz Media.

Gardner. 2009. Kecerdasan Majemuk. (Terjemahan Drs. Alexander Sindoro). Batam Centre: Interaksara.

Hilda, F. 2012. Bermain Untuk Anak Usia Dini. Bandung: Rikaneka.

May, L. 2008. Cara Mengembangkan Berbagai Komponen Kecerdasan. Yogyakarta: PT. Indeks.
Miller. 2002. Early education Curiculum A child'S connection to the word. Apendix.

Mulyasa. 2004. Model Pembelajaran Untuk Anak. Jakarta: Grasindo.

Safaria, T. (t.thn.). Interpersonal IntelligenceMetode Pengembangan Kecerdasan Interpersonal Anak. Yogyakarta: Amara Books.

Sanjaya, W. 2009. Strategi Pembelajaran. Prenada Media Group.

Sujiono. 2010. Bermain kreatif berbasis kecerdasan jamak. Jakarta: index.

Sujiono, Yuliani Nurani, Dkk. 2008. Metode Pengembangan Kognitif. Jakarta: Universitas Terbuka.

Suyadi. 2010. Panduan Penelitian Tindakan Kelas: Buku Panduan Wajib bagi Para Pendidik. Banguntapan Jogjakarta: DIVA Press. 